\title{
Sport and Nutrition Journal
}

Vol 1 No 2 - November 2019 (63-73)

https://journal.unnes.ac.id/sju/index.php/spnj/

\section{Tingkat Stres, Durasi dan Kualitas Tidur, Serta Sindrom Makan Malam Pada Mahasiswi Obesitas Dan Non Obesitas Fakultas Kedokteran}

\author{
Adilla Eka Afriani ${ }^{1 *}$, Ani Margawati ${ }^{1}$, Fillah Fithra Dieny ${ }^{1}$ \\ ${ }^{1}$ Program Studi S1 IImu Gizi Fakultas Kedokteran Universitas Diponegoro Semarang \\ adillaeka136@yahoo.com
}

\begin{abstract}
ABSTRAK
Obesitas merupakan suatu kelainan yang ditandai dengan penimbunan jaringan lemak tubuh secara berlebihan. Tingkat stress, kualitas dan durasi tidur serta sindrom makan malam merupakan salah satu faktor risiko terjadinya obesitas. Tujuan penelitian untuk menganalisis perbedaan tingkat stres, kualitas dan durasi tidur, serta sindrom makan malam pada mahasiswi obesitas dan non obesitas fakultas kedokteran Penelitian ini menggunakan desain case-control, dengan jumlah responden sebanyak 36 subjek mahasiswi obesitas sebagai kelompok kasus dan 36 mahasiswi non obesitas sebagai kelompok kontrol di Fakultas Kedokteran Universitas Diponegoro. Pengambilan subjek menggunakan metode simple random sampling. Data meliputi tingkat stress, durasi dan kualitas tidur, sindrom makan malam, asupan makan dan aktivitas fisik masing- masing diukur menggunakan Depression Anxiety Stres Scale 42 (DASS 42), Pittsburgh Sleep Quality Index (PSQI), The Night Eating Questionnaire (NEQ), food recall, dan International Physical Activity Quetionnaire (IPAQ). Analisis data menggunakan uji independent $t$ test dan Mann Whitney. Rerata kualitas dan durasi tidur pada kelompok kasus sebesar 8,4 $\pm 2,7$ dan 5,9 $\pm 1,3$ jam, sedangkan pada kelompok kontrol sebesar $7,1 \pm 2,3$ dan $6,5 \pm 1,3$ jam. Ada perbedaan durasi tidur $(p=0,025)$, kualitas tidur $(p=0,030)$, dan asupan protein $(p=0,044)$ antara kelompok obesitas dan non obesitas. Namun, tidak terdapat perbedaan tingkat stress $(p=0,768)$ dan sindrom makan malam $(p=0,722)$ antara kelompok obesitas dan non obesitas). Terdapat perbedaan kualitas tidur, durasi tidur dan asupan protein pada kelompok obesitas dan non obesitas.
\end{abstract}

Kata Kunci : tingkat stres, kualitas tidur, durasi tidur, sindrom makan malam, obesitas

\begin{abstract}
Obesity identified by abnormality marked by fat accumulation of body tissue excessively. Stress levels, duration and sleep quality, and night eating syndrome is one of risk factors for obesity. The objective of the study was to analyze the difference between stress levels, duration and sleep quality, and night eating syndrome among obese and non-obese students of the Faculty of Medicine. This study was case control design. This research was conducted at Medical Faculty Diponegoro University. Subjects were 36 obese students as a case group and were 36 non obese students as a control group. Subjects were chosen through simple random sampling methods. Data of stress levels, duration and quality of sleep, night eating sindrom, nutrient intake and physical activity were measured by the Depression Anxiety Stress Scale 42 (DASS 42), the Pittsburgh Sleep Quality Index (PSQI), The Night Eating Questionnaire (NEQ), food recall and International Physical Activity Questionnaire (IPAQ), respectively. Data were analyzed using independent t-test and Mann Whitney. The average of duration and sleep quality of the case group was $8.4 \pm 2.7$ and $5.9 \pm 1.3$ hours, while the control group it was $7.1 \pm 2.3$ and $6.5 \pm 1.3$ hours. There were significant differences of sleep quality $(p=0,030)$, sleep duration $(p=0,025)$ and protein intake $(p=0,044)$ in between obese and non obese. There were no significant difference of stress levels $(p=0,768)$ and night eating syndrome $(p=0,722)$ between obese and non obese. Conclusion: There were significant differences of sleep quality, sleep duration and protein intake between obese and non obese groups.
\end{abstract}

Key words : stress levels, sleep quality, sleep duration, night eating syndrome, obesity 


\section{PENDAHULUAN}

Obesitas merupakan akumulasi lemak berlebihan yang dapat menyebabkan risiko gangguan kesehatan. World Health Organization (WHO) menempatkan obesitas sebagai masalah epidemik global sejak tahun 2005. WHO melaporkan bahwa pada tahun 2015 sebanyak $\pm 2,3$ milyar orang dewasa memiliki berat badan berlebih dan 700 juta diantaranya termasuk dalam golongan obesitas (WHO, 2011). Prevalensi obesitas di Indonesia menurut Riset Kesehatan Dasar (Riskesdas) 2013 mengalami peningkatan dibandingkan dengan Riskesdas 2010. Angka kejadian obesitas pada penduduk perempuan dewasa ( $>18$ tahun) pada tahun 2010 sebanyak 15,5\% kemudian meningkat menjadi 32,9\% pada tahun 2013 (Riskesdas, 2013). Profil kesehatan Kabupaten Semarang menyebutkan bahwa angka obesitas sebesar $10,4 \%$ pada usia $>15$ tahun (Dinkes Kabupaten Semarang, 2016). Prevalensi kejadian obesitas pada perempuan relatif lebih tinggi dibanding dengan laki-laki (Prameswari, 2013).

Prevalensi obesitas golongan usia dewasa menunjukkan adanya peningkatan disertai dengan penurunan rata-rata durasi tidur (Bayon et al, 2014). Hasil penelitian di Kanada menyatakan bahwa orang dewasa dengan obesitas memiliki durasi tidur yang lebih pendek dibandingkan dengan orang dewasa yang tidak obesitas (Yannakouli et al, 2010). Durasi tidur menjadi regulator penting pada berat badan dan metabolisme. Tidur yang kurang dapat menyebabkan gangguan regulasi hormonal terutama pengeluran hormon leptin dan ghrelin yang berdampak pada pengaturan nafsu makan dan jumlah asupan makan (Taheri et al, 2004). Selama satu abad terakhir terjadi penurunan ratarata waktu tidur seseorang dari 9 jam menjadi 6,8 jam per hari dengan jumlah persentase mencapai $30 \%$ orang dewasa hanya tidur kurang dari $5 \mathrm{jam} /$ hari (Sharma, 2010). Penurunan kualitas dan kuantitas tidur dipengaruhi oleh perasaan dan pikiran seseorang, seperti stres dan rasa cemas (Sendir et al, 2007). National Sleep Foundation menyatakan bahwa pada usia dewasa muda dianjurkan untuk tidur dengan waktu 7-9 jam setiap malam (NSF, 2010). Kebutuhan tidur seseorang yang cukup ditentukan dari jumlah jam tidur (kuantitas tidur) dan kedalaman tidur (kualitas tidur). Kualitas tidur yang buruk mengakibatkan kesehatan fisiologis dan psikologis menurun. Kualitas tidur yang buruk secara fisiologis dapat menyebabkan rendahnya tingkat kesehatan individu dan meningkatkan kelelahan atau mudah letih bahkan secara psikologis mengakibatkan ketidakstabilan emosional, kurang percaya diri, impulsif yang berlebihan dan kecerobohan (Sulistiyani C, 2012).

Mahasiswa memiliki berbagai tuntutan akademik sehingga hal tersebut dapat menjadi stresor bagi mahasiswa. Pada mahasiswa di Fakultas Kedokteran, sering mengalami stres dan kecemasan yang diakibatkan karena terjadi perubahan lingkungan sosial dan lingkungan belajar. Mahasiswa dituntut untuk menjadi seorang yang berpengetahuan, berkeahlian serta professional sehingga dapat mengakibatkan perubahan psikologis terhadap mahasiswa (Wei, 2005; Dinn, 2008). Penelitian di Fakultas Kedokteran Universitas Tanjungpura menyatakan bahwa mahasiswa kedokteran juga sering mengalami tekanan sehingga menimbulkan gejala stres ringan hingga sangat berat $(86,4 \%)$ (Melvy, 2017). Kondisi stres pada seseorang dapat mengakibatkan adanya gangguan tidur sehingga memungkinkan terjadinya aktivitas makan di malam hari. Kebiasaan makan di malam hari dapat memungkinkan terjadinya Sindrom Makan Malam (SMM). Individu dengan SMM memiliki kebiasaan mengkonsumsi asupan makan setelah jam 19.00 (Gluck, 2001) Makan malam dinilai lebih berperan menyebabkan kegemukan dibandingkan sarapan dan makan siang (Yannakoulia, 2010).

Penelitian di New York menyimpulkan bahwa SMM dihubungkan dengan pola makan secara patologi, gangguan tidur dan emosi. Kadar hormon melatonin dan leptin yang rendah serta meningkatnya hormone kortisol ditemukan pada orang dengan SMM (Gluck, 2001). Kondisi SMM ini tidak hanya ditemukan pada individu obesitas, namun juga pada individu non-obese (Lungren, 2008). Berdasarkan latar belakang diatas, maka peneliti tertarik untuk meneliti perbedaan tingkat stres, kualitas tidur, durasi tidur dan sindrom makan malam antara mahasiwi obesitas dan non obesitas di Fakultas Kedokteran Universitas Diponegoro.

\section{METODE PENELITIAN}

Penelitian ini merupakan penelitian observasionalmenggunakandesaincase-control. Penelitian dilaksanakan pada bulan Agustus sampai Oktober 2018 di Fakultas Kedokteran Universitas Diponegoro dengan rekomendasi Ethical Clearance nomor: 574/ EC/ FK-RSDK/ VII/ 2018. Subjek dalam penelitian ini adalah mahasiswi usia 18-21 tahun dengan dengan IMT 
$\geq 25 \mathrm{~kg} / \mathrm{m} 2$ untuk kelompok kasus dan IMT 18,5$22,9 \mathrm{~kg} / \mathrm{m} 2$ untuk kelompok kontrol. Besar subjek penelitian sebanyak 72 orang, dengan 36 orang untuk masing-masing kelompok. Kriteria inklusi subjek antara lain bersedia menjadi subyek penelitian dengan mengisi informed consent, tercatat sebagai mahasiswi aktif di Fakultas Kedokteran Universitas Diponegoro berusia 1821 tahun dan mampu berkomunikasi dengan baik. Kriteria eksklusi adalah subjek mengalami sakit dan tidak dapat dihubungi. Pengambilan subjek dilakukan dengan metode simple random sampling. Variabel terikat dalam penelitian ini adalah kejadian obesitas, sedangkan variabel bebas adalah tingkat stres, kualitas dan durasi tidur serta sindrom makan malam. Variabel yang diduga perancu adalah asupan energi, karbohidrat, lemak, protein, serat dan aktivitas fisik.

Stres dalam arti umum merupakan pola reaksi serta adaptasi umum, dalam arti pola reaksi menghadapi stresor, yang dapat berasal dari dalam maupun luar individu yang bersangkutan, dapat nyata maupun tidak nyata sifatnya. Data tingkat stres diperoleh dari kuesioner Depression Anxiety Stres Scale 42 (DASS 42) dengan hasil skoring kuesioner pada subjek dikategorikan normal (0-14), ringan (15$18)$, sedang (19-25), berat (26-33) dan sangat berat $(>34)$ (Musradinur, 2016). Kualitas tidur adalah kemampuan individu untuk dapat tetap tidur, tidak hanya mencapai jumlah atau lamanya tidur (Sulistiyani C, 2012). Durasi tidur adalah waktu seseorang tidur sampai terbangun di pagi hari tanpa menyebutkan terbangun pada tengah malam (Lestari R, 2018). Data kualitas dan durasi tidur diperoleh dari kuisioner Pittsburgh Sleep Quality Index (PSQI) (Fandiani, 2017). Kemudian hasil pengukuran dikategorikan subjek dengan kualitas tidur baik $(\leq 5)$ dan buruk $(>5)$. Selanjutnya untuk mengetahui durasi tidur malam pada subjek dengan menggunakan metode skoring nomer 4 yang mengkalkulasi antara waktu tidur malam dengan waktu bangun tidur di pagi hari. Hasil pengukuran kemudian dikategorikan durasi tidur malam kurang $(<7$ jam/hari) dan cukup (7-9 jam/hari) (NSF, 2010). Sindrom makan malam (SMM) adalah gangguan yang sangat spesifik di mana individu yang terkena bangun beberapa kali pada malam hari dan tidak dapat kembali untuk tidur kecuali mereka memakan sesuatu (Milano et al, 2012). Data sindrom makan malam diperoleh dari kuisioner The Night Eating Questionnaire (NEQ) (Omar, 2007). Hasil pengukuran dikategorikan termasuk kedalam SMM $(\geq 25)$ dan tidak SMM $(<25)$ pada kuesioner.

Data asupan zat gizi merupakan ratarata makanan dan minuman yang diperoleh dengan wawancara menggunakan food recall $3 \times 24$ jam. Analisis asupan energi, karbohidrat, lemak, protein dan serat menggunakan aplikasi Nutrisurvey 2005. Setelah dianalisis, asupan zat gizi dibandingkan dengan total kebutuhan setiap individu, subjek dikategorikan kurang $(<90 \%)$, cukup $(90-119 \%)$ dan lebih $(>120 \%)$ (Wahyuningsih R, 2013). Aktivitas fisik adalah setiap gerakan tubuh yang dihasilkan oleh otot rangka yang memerlukan pengeluaran energi (Muzamil, 2014). Data aktivitas fisik diperoleh dari kuesioner International Physical Activity Quetionnaire (IPAQ). Subjek dalam kategori aktivitas fisik berat jika aktivitas intensitas berat 3 hari atau lebih atau kombinasi berjalan, aktivitas intensitas berat, dan sedang yang mencapai minimal $3000 \mathrm{METs}-m e n i t / m i n g g u$, aktivitas fisik sedang jika lima hari atau lebih kombinasi dari aktivitas berjalan, aktivitas fisik sedang dan aktivitas fisik berat mencapai total MET minimal $600 \mathrm{MET}$-menit/minggu, aktivitas fisik rendah jika total aktivitas fisik seseorang tidak mencakup kategori tinggi atau sedang dan total MET < $600 \mathrm{MET}$-menit/minggu (Hamrik, 2014). Analisis univariat digunakan untuk menggambarkan variabel.

Analisis univariat dilakukan untuk mendeskripsikan variabel. Uji kenormalan data menggunakan Kolmogorov-Smirnov. Analisis bivariat dilakukan untuk mengetahui perbedaan masing-masing variabel dengan variabel terikat dengan menggunakan uji independent t-test apabila data berdistribusi normal dan apabila data berdistribusi tidak normal menggunakan Mann Whitney.

\section{HASIL DAN PEMBAHASAN \\ Gambaran Umum Penelitian}

Hasil penelitian menunjukkan bahwa tingkat stres pada mahasiswi FK UNDIP tidak jauh berbeda antara kelompok obesitas dan non obesitas. Kelompokkasuslebihbanyakmengalami tingkat stres ringan sebanyak 9 responden $(25 \%)$ dan kelompok kontrol sebanyak 6 orang $(16,7 \%)$. 
Tabel 1. Distribusi Frekuensi Tingkat Stres, Durasi Tidur, Kualitas Tidur, Sindrom Makan Malam, Asupan Zat Gizi dan Aktivitas Fisik

\begin{tabular}{|c|c|c|c|c|}
\hline \multirow{2}{*}{ Variabel } & \multicolumn{2}{|c|}{ Kasus } & \multicolumn{2}{|c|}{ Kontrol } \\
\hline & $\mathbf{n}$ & $\%$ & $\mathbf{n}$ & $\%$ \\
\hline \multicolumn{5}{|l|}{ Tingkat Stres (\%) } \\
\hline Normal & 20 & 55,6 & 19 & 52,8 \\
\hline Ringan & 9 & 25 & 6 & 16,7 \\
\hline Sedang & 5 & 13,9 & 8 & 22,2 \\
\hline Berat & 2 & 5,6 & 2 & 5,6 \\
\hline Sangat Berat & 0 & 0 & 1 & 2,8 \\
\hline \multicolumn{5}{|c|}{ Durasi Tidur Malam (\%) } \\
\hline Kurang & 16 & 44,4 & 7 & 19,4 \\
\hline Cukup & 20 & 55,6 & 29 & 80,6 \\
\hline \multicolumn{5}{|c|}{ Kualitas Tidur (\%) } \\
\hline Baik & 1 & 2,8 & 11 & 30,6 \\
\hline Buruk & 35 & 97,2 & 25 & 69,4 \\
\hline \multicolumn{5}{|l|}{ SMM (\%) } \\
\hline Tidak SMM & 32 & 88.9 & 29 & 80,6 \\
\hline SMM & 4 & 11,1 & 7 & 19,4 \\
\hline \multicolumn{5}{|l|}{ Energi (\%) } \\
\hline Kurang & 34 & 94,4 & 34 & 94,4 \\
\hline Cukup & 2 & 5,6 & 2 & 5,6 \\
\hline \multicolumn{5}{|l|}{ Lemak (\%) } \\
\hline Kurang & 30 & 83,3 & 24 & 66,7 \\
\hline Cukup & 4 & 11,1 & 9 & 25 \\
\hline Lebih & 2 & 5,6 & 3 & 8,3 \\
\hline \multicolumn{5}{|l|}{ Protein (\%) } \\
\hline Kurang & 35 & 97,2 & 34 & 94,4 \\
\hline Cukup & 1 & 2,8 & 2 & 5,6 \\
\hline \multicolumn{5}{|l|}{ Karbohidrat (\%) } \\
\hline Kurang & 35 & 97,2 & 35 & 97,2 \\
\hline Cukup & 1 & 2,8 & 1 & 2,8 \\
\hline \multicolumn{5}{|l|}{ Serat (\%) } \\
\hline Kurang & 36 & 100 & 36 & 100 \\
\hline \multicolumn{5}{|c|}{ Aktivitas Fisik (\%) } \\
\hline Ringan & 17 & 47,2 & 21 & 58,3 \\
\hline Sedang & 12 & 33,3 & 9 & 25 \\
\hline Berat & 7 & 19,4 & 6 & 16,7 \\
\hline
\end{tabular}

Tingkat stres sedang lebih banyak dialami oleh kelompok kontrol yaitu sebanyak delapan responden $(22,2 \%)$ dibandingkan dengan kelompok kasus sebanyak lima responden $(13,9 \%)$. Durasi tidur malam pada kedua kelompok rata-rata cukup tetapi jumlah durasi tidur malam $<7$ jam/hari lebih banyak dialami pada kelompok kasus $(44,4 \%)$ dibandingkan dengan kelompok kontrol $(19,4 \%)$. Responden dengan kualitas tidur yang buruk lebih banyak dialami oleh kelompok kasus $(97,2 \%)$ dibandingkan dengan kelompok kontrol $(69,4 \%)$. SMM ditemukan lebih banyak dialami oleh kelompok kontrol $(19,4 \%)$ dibandingkan dengan kelompok kasus $(11,1 \%)$. Aktivitas fisik ringan lebih dipilih oleh kedua kelompok dengan kelompok kasus sebanyak 17 orang $(47,2 \%)$ dan kelompok kontrol sebanyak 21 orang $(58,3 \%)$. 
Tabel 2. Analisis Bivariat Tingkat stres, Durasi Kualitas Tidur, Sindrom Makan Malam dan Variabel Perancu dengan Kejadian Obesitas

\begin{tabular}{|c|c|c|c|c|c|c|c|}
\hline \multirow[t]{2}{*}{ Variabel } & Kasus & \multicolumn{5}{|c|}{ Kontrol } & \multirow[t]{2}{*}{$p$} \\
\hline & Mean士SD & Min & Maks & Mean士SD & Min & Maks & \\
\hline Tingkat Stres (skor) & $13,9 \pm 6$ & 3 & 30 & $14,4 \pm 7,5$ & 1 & 35 & $0,768^{\mathrm{a}}$ \\
\hline Kualitas Tidur (skor) & $8,4 \pm 2,7$ & 4 & 15 & $7,1 \pm 2,3$ & 3 & 13 & $0,030^{b}$ \\
\hline $\begin{array}{l}\text { Durasi Tidur Malam } \\
\text { (jam) }\end{array}$ & $5,9 \pm 1,3$ & 4 & 7 & $6,5 \pm 1,3$ & 4 & 8 & $0,025^{b}$ \\
\hline $\begin{array}{l}\text { Sindrom Makan Malam } \\
\text { (skor) }\end{array}$ & $16,8 \pm 5,7$ & 8 & 35 & $17,6 \pm 6,9$ & 7 & 40 & $0,722^{\mathrm{b}}$ \\
\hline $\begin{array}{l}\text { Aktivitas Fisik (MET- } \\
\text { menit/minggu) }\end{array}$ & $1221 \pm 1,4$ & 0 & 5558 & $1289 \pm 1,7$ & 0 & 7779 & $0,612^{b}$ \\
\hline Energi (kkal) & $1122 \pm 4,2$ & 643 & 2838 & $1127 \pm 3,2$ & 452 & 2009 & $0,362^{b}$ \\
\hline Protein $(g)$ & $43,8 \pm 12,9$ & 24,8 & 96,7 & $39,2 \pm 11,3$ & 14,3 & 72,2 & $0,044^{b}$ \\
\hline Lemak (g) & $47,1 \pm 21,6$ & 21,8 & 146,3 & $44,9 \pm 14$ & 14,4 & 77,2 & $0,826^{\mathrm{b}}$ \\
\hline Karbohidrat (g) & $\begin{array}{r}117,8 \pm 56 \\
2\end{array}$ & 41 & 287,4 & $\begin{array}{r}123,5 \pm 38 \\
6\end{array}$ & 68,6 & 253,8 & $0,136^{\mathrm{b}}$ \\
\hline Serat (g) & $6,3 \pm 3$ & 1,8 & 16 & $6,1 \pm 2,4$ & 3 & 12,8 & $0,884^{b}$ \\
\hline
\end{tabular}

\section{${ }^{a}$ Uji Independent $T$ test ${ }^{b}$ Uji Mann-Whitney}

Tabel 2 menunjukkan bahwa pada kelompok kasus dan kelompok kontrol memiliki kualitas tidur buruk yang ditandai dengan jumlah skor $>5$. Rata- rata durasi tidur malam pada kelompok kasus adalah 5,9 jam dan 6,5 jam pada kelompok kontrol. Nilai minimum 4 jam pada kedua kelompok, sedangkan nilai maksimum sebesar 7 jam pada kelompok kasus dan 8 jam pada kelompok kontrol. Hal ini menandakan bahwa pada kedua kelompok, responden memiliki durasi tidur malam paling pendek \pm 4 jam/hari.

Pada analisis bivariat, diperoleh hasil bahwa terdapat perbedaan kualitas tidur, durasi tidur malam dan asupan protein antara kelompok obesitas dan non obesitas $(p<0,05)$. Namun, ditemukan tidak ada perbedaan tingkat stres, SMM, aktivitas fisik, asupan energi, lemak, karbohidrat dan serat antara kelompok obesitas dan non obesitas $(p>0,05)$. Asupan zat gizi pada kedua kelompok rata-rata kurang dari kebutuhan, serta asupan serat pada kedua kelompok ditemukan kurang dari kebutuhan yaitu $25 \mathrm{gram} /$ hari. Rerata asupan serat pada kelompok kasus 6,3 gram dan 6,1 gram pada kelompok kontrol.

Tingkat Stres, Kualitas Tidur, Durasi Tidur, Sindrom Makan Malam, Asupan Zat Gizi dan Aktivitas Fisik

Analisis bivariat menunjukkan adanya perbedaan kualitas tidur antara mahasiswi obesitas dan non obesitas $(p=0,03)$ dengan rata- 
rata kualitas tidur pada kelompok mahasiswi obesitas memiliki skor yang lebih tinggi $(8,4 \pm 2,7)$ dibandingkan dengan skor mahasiswi non obesitas $(7,1 \pm 2,3)$. Hal ini disebabkan karena mahasiswi obesitas cenderung mengalami gangguan saat tidur seperti gangguan pernafasan (sleep apnea) yang ditandai dengan mendengkur pada saat tidur, posisi tidur yang tidak benar sehingga susah bernafas dan sering terjaga di malam hari. Kualitas tidur yang buruk juga dapat disebabkan oleh kebiasaan mahasiswi tidur larut malam, menonton, bermain game dan menggunakan handphone. Hasil penelitian ini juga sejalan dengan penelitian yang dilakukan pada mahasiswa Fakultas Kesehatan Masyarakat Universitas Diponegoro yang menyatakan adanya hubungan signifikan antara IMT dan kualitas tidur $(p=0,013)$. Penelitian tersebut juga menyatakan bahwa mahasiswa dengan kategori IMT kurus lebih cenderung memiliki kualitas tidur yang baik. Kualitas tidur yang baik pada mahasiswa dengan kategori IMT kurus dikarenakan tidak mengalami sleep apnea sehingga lebih mudah untuk tidur dan merasa nyenyak saat tidur. Kualitas tidur yang baik dapat memberikan efek seperti merasa segar saat bangun, tidak mengantuk saat beraktivitas, dan tidak merasakan keletihan saat beraktivitas (Sulistiyani C, 2012) Kualitas tidur yang buruk dengan gaya hidup yang tidak baik dalam jangka waktu lama akan menyebabkan peningkatan IMT seseorang bahkan dalam kategori obesitas (Marfuah, 2015).

Analisis bivariat selanjutnya menunjukkan adanya perbedaan durasi tidur antara mahasiswi obesitas dengan mahasiswi non obesitas $(p=0,025)$. Hasil pengukuran menunjukkan rata-rata durasi tidur malam pada kelompok mahasiswi obesitas $<7$ jam/hari $(5,9 \pm 1,3$ jam $)$ sedangkan rata-rata pada mahasiswi non obesitas sudah mencapai $\geq 7$ jam/hari $(6,5 \pm 1,3$ jam). National Sleep Foundation menganjurkan pada usia dewasa muda memiliki waktu tidur sebanyak 7-9 jam setiap malam (NSF, 2010). Durasi tidur malam yang kurang pada mahasiswi obesitas dikarenakan adanya masalah gangguan tidur yang menyebabkan sering terjaga ditengah malam sehingga sulit untuk tidur kembali. Hal ini yang menyebabkan para mahasiswi obesitas tersebut tidak dapat mencukupi waktu durasi tidur yang baik. Beberapa responden memiliki durasi tidur yang kurang disebabkan oleh kebiasaan tidur larut malam dan kemudian harus bangun di pagi hari untuk kuliah. Hal ini sejalan dengan penelitian yang dilakukan oleh
Debby dkk, yaitu prevalensi orang dewasa yang memiliki durasi tidur $<7$ jam /hari pada kelompok obesitas $42 \%$ lebih besar dibandingkan dengan prevalensi orang dewasa tidak obesitas yang durasi tidurnya $>7$ jam/hari. Hubungan durasi tidur yang pendek dengan terjadinya obesitas pada orang dewasa dapat dijelaskan dengan beberapa mekanisme. Durasi tidur yang lebih sedikit dapat meningkatkan asupan energi dan menurunkan pegeluaran energi (Safitri, 2015). Perubahan yang terjadi bila seseorang kurang tidur antara lain adalah perubahan metabolisme tubuh dan hormonal. Metabolisme tubuh pada saat tidur $5 \%$ lebih rendah dibandingkan saat bangun. Pada orang yang tidur $<7$ jam/hari, kadar hormon leptin dan melatonin berkurang (Farooqi, 1999). Kadar hormon melatonin tinggi ditemukan pada kondisi tidur. Hormon melatonin membuat kadar hormon leptin meningkat (Arendt, 2000). Ghrelin akan menurun jika jumlah jam tidur orang dewasa cukup ( $\geq 7$ jam). Waktu tidur yang kurang dapat menyebabkan terjadinya penurunan kadar hormon kortisol (hormon yang berperan dalam pengaturan laju metabolisme) serta kadar growth hormone (hormon yang berperan penting di dalam pembakaran lemak dan pembentukan otot) (Spiegel, 2004).

Hasil penelitian menunjukkan tidak ada perbedaan yang bermakna mengenai tingkat stres antara mahasiswi obesitas dan non obesitas $(p=0,768)$. Kelompok kasus dan kelompok kontrol memiliki rata-rata tingkat stres dalam kategori normal. Penelitian ini juga menunjukkan skor tingkat stres pada mahasiswi obesitas lebih rendah $(13,9 \pm 6)$ dibandingkan dengan skor mahasiswi non obesitas $(14,4 \pm 7,5)$. Mahasiswi obesitas lebih banyak mengalami tingkat stres ringan dan tingkat stres sedang lebih banyak dialami oleh mahasiswi non obesitas, akan tetapi jumlah tingkat stres ringan dan sedang antara kedua kelompok ditemukan tidak berbeda. Faktor risiko yang menyebabkan mahasiswa mengalami stres diantaranya adalah lingkungan, akademik, persaingan, hubungan interpersonal dan cara berpikir. Status gizi subyek juga dimungkinkan sebagai penyebab keadaan stres pada responden sehingga mahasiswi non obesitas juga memiliki risiko mengalami stres sama dengan mahasiswi non obesitas. Hasil penelitian ini sejalan dengan penelitian pada mahasiswa UNS yang menunjukkan bahwa stres tidak berhubungan dengan IMT $(p=0.491)$. Tidak ada hubungan antara stres dengan IMT dikarenakan pada keadaan stres, seseorang cenderung lupa akan kebutuhan makan, kebersihan diri dan 
istirahat. Pilihan makan selama periode stres juga dapat mempengaruhi status gizi seperti adanya kecenderungan makan lebih banyak bahkan kecenderungan makan dalam jumlah sedikit (Wardani, 2015).

Penelitian pada mahasiswa Fakultas Kedokteran UNSRAT juga menunjukkan hasil yang sejalan dengan penelitian ini yakni sebagian besar mahasiswa memiliki tingkat stres rendah dan ada juga yang mengalami tingkat stres tinggi. Penilaian individu terhadap stressor dapat mempengaruhi kemampuan individu untuk melakukan tindakan pencegahan terhadap stressor yang membuat stres. Govaerest \& Gregoire mengatakan bahwa respon seseorang berhadapan dengan stressor tidak akan sama dengan saat pertama kali, seseorang cenderung lebih dapat mengelolah stressor ketika dihadapkan dalam kondisi yang berulang. Setiap mahasiswa tentunya memiliki pengalaman yang berbeda dan dipersepsikan berbeda walaupun dengan stressor yang sama, sehingga tingkat stres yang dialami oleh mahasiswa juga bervariasi tergantung dari pengalaman stres akademik individu tersebut (Bingku, 2015).

Hasil penelitian menunjukkan tidak terdapat perbedaan SMM antara mahasiswi obesitas dan non obesitas $(p=0,722)$. Responden pada kelompok kasus ataupun kelompok kontrol mengalami SMM dengan jumlah sedikit. Rerata skor SMM pada mahasiswi non obesitas lebih tinggi $(17,6 \pm 6,9)$ dibandingkan dengan mahasiswi obesitas $(16,8 \pm 5,7)$. Hasil penelitian menemukan pada kelompok kasus sebanyak empat orang mahasiswi $(11,1 \%)$ dan pada kelompok kontrol sebanyak tujuh orang mahasiswi $(19,4 \%)$ yang mengalami SMM. SMM lebih banyak terjadi pada responden non obesitas dikarenakan adanya faktor seperti kepercayaan diri, stres dan depresi. Hal ini sejalan dengan hasil penelitian pada mahasiswa Universitas Indonesia yaitu tidak terdapat hubungan yang bermakna antara status gizi dengan SMM ( $p=0,600)$. Orang gemuk dan tidak gemuk yang memiliki kriteria SMM memiliki jumlah perbedaan yang kecil (Parastika, 2012). Beberapa hasil penelitian menemukan bahwa SMM pada orang tidak gemuk tidak bisa disepelekan, meskipun kegemukan belum terlihat sebagai dampak saat ini. Pada pemakan malam yang non obes menunjukkan bahwa SMM berhubungan dengan pola makanan yang abnormal, perilaku makan yang tidak teratur, gangguan tidur, suasana hati, peningkatan stres, penurunan kualitas hidup, dan kemungkinan yang lebih besar dari psikopatologi. Pemakan malam dilaporkan memiliki suasana hati yang lebih tertekan dan stres yang dirasakan dan yang secara signifikan memiliki kualitas hidup yang lebih rendah (Lundgren, 2008).

Variabel perancu dalam penelitian ini adalah asupan energi, lemak, protein, karbohidrat, serat dan aktivitas fisik. Hasil penelitian pada asupan energi menunjukkan tidak terdapat perbedaan antara mahasiswi obesitas dengan non obesitas $(p=0,362)$. Rerata asupan energi pada kedua kelompok ditemukan tidak jauh berbeda yaitu $1122 \pm 4,2$ kkal pada kelompok mahasiswi obesitas dan 1127 $\pm 3,2$ kkal pada kelompok mahasiswi non obesitas. Kelompok kasus menunjukkan bahwa sebanyak 94,4\% responden memiliki asupan energi yang kurang. Hal tersebut dapat terjadi karena pada mahasiswi obesitas cenderung membatasi jumlah konsumsi makanan karena takut berat badan akan mengalami kenaikan dan beberapa mahasiswi juga mengungkapkan porsi makanan yang sedikit dan beberapa lainnya disebabkan terjadinya bias karena mahasiswi lupa. Rerata asupan energi mahasiswi diperoleh dari sumber energi yaitu nasi, roti, kentang, mie bihun, mie instan, dan dari jenis umbi-umbian. Hal tersebut sejalan dengan penelitian Vicennia dkk yaitu didapatkan hasil bahwa sebanyak $70 \%$ dari responden mahasiswa Fakultas Kedokteran Universitas Riau belum memiliki asupan energi yang cukup. Hal tersebut disebabkan karena kurangnya dukungan dari lingkungan, sulitnya mendapatkan makanan yang sehat, hambatan seseorang tidak dapat merubah kebiasaan makannya menjadi lebih baik. Penyebab lainnya adalah karena sebagian besar mahasiswi hidup tinggal di kos sehingga makanan yang dikonsumsi tidak beragam. Berbeda dengan mereka yang tinggal di rumah, karena diasumsikan bahwa dengan tinggal di rumah asupannya lebih terjaga, lebih sehat, dan dalam variasi maupun ketersediannnya pun juga mencukupi (Serly, 2015).

Kemudian berdasarkan hasil uji bivariat terdapat perbedaan asupan protein yang signifikan antara mahasiswi obesitas dan non obesitas $(p=0,044)$, rerata asupan protein pada kelompok mahasiswi obesitas lebih tinggi $(43,8 \pm 12,9$ gram $)$ dibandingkan kelompok mahasiswi non obesitas $(39,2 \pm 11,3$ gram). Namun ditemukan asupan protein pada kedua kelompok sebagian besar masih kurang dari kebutuhan, sehingga perbedaan asupan protein pada kedua kelompok ini tidak bisa dikatakan sebagai penyebab terjadinya obesitas pada 
mahasiswi. Hasil food recall $3 \times 24$ jam pada mahasiswi obesitas menunjukkan bahwa sumber protein hewani berasal dari daging ayam dan telur, sedangkan untuk protein nabati berasal dari kacang-kacangan. Selanjutnya, pada mahasiswi non obesitas sumber protein lebih bervariasi yaitu berasal dari daging sapi, daging ayam, telur dan susu, sedangkan untuk protein nabati yaitu tahu dan tempe. Saat menghindari makanan berlemak dan karbohidrat, seseorang cenderung mengonsumsi protein sebagai pengganti. Namun menurut Prof Ali protein juga dapat menyebabkan kegemukan (Khomsan, 2003).

Perbedaan asupan lemak pada mahasiswi obesitas dan non obesitas tidak signifikan $(p=0,826)$. Nilai rerata asupan lemak kedua kelompok sebagian besar masih kurang dari kebutuhan individu, yaitu pada mahasiswi obesitas sebesar $47,1 \pm 21,6$ gram dan pada kelompok mahasiswi non obesitas sebesar $44,9 \pm 14$ gram. Namun ditemukan kelebihan asupan lemak lebih banyak ditemukan pada mahasiswi non obesitas (8,3\%) dibandingkan dengan mahasiswi obesitas (5,6\%). Hal ini disebabkan karena mahasiswi obesitas mulai memikirkan body image dibandingkan dengan mahasiswi non obesitas, sehingga rata-rata mereka mengurangi makanan sumber lemak sebagai upaya dalam menurunkan berat badan. Hal ini sejalan dengan penelitian yang dilakukan oleh Fajar yaitu tidak terdapat perbedaan ratarata pada asupan lemak obese dan tidak obese pada mahasiswa obese dengan non obese di Fakultas Kedokteran Universitas Sam Ratulangi. Hasil penelitian tersebut didapat bahwa ratarata konsumsi lemak pada orang tidak obese lebih besar dibandingkan orang yang obese (Aprilianti, 2013). Hal ini diduga karena pada penelitian hanya diambil satu kali food recall 24 jam dan pada peneliti hanya menanyakan frekuensi makanan berlemak dan tidak mengukur besarnya kontribusi energi dari makanan berlemak yang dikonsumsi sampel sehingga hasil yang diperoleh tidak menggambarkan kondisi konsumsi makanan berlemak sampel sebenarnya (Sugianti, 2009). Kemungkinan ada faktor lain yang mempengaruhi status gizi lebih seperti ketidaknormalan produksi hormon seseorang dapat meningkatkan resiko obesitas (Sasmito, 2013).

Pada asupan karbohidrat tidak memiliki perbedaan antara mahasiswi obesitas dengan non obesitas $(p=0,136)$. Sebanyak $97,2 \%$ responden memiliki asupan karbohidrat yang kurang dengan rerata $117,8 \pm 56,2$ gram pada mahasiswi obesitas dan $123,5 \pm 38,6$ gram pada mahasiswi non obesitas. Hal tersebut dapat disebabkan karena. mahasiswi lebih memilih makanan dengan karbohidrat yang tidak terlalu besar dikarenakan mereka sudah mengetahui bahwa tinggi karbohidrat tidak baik untuk bentuk badan. Beberapa dari mahasiswi juga pernah menghindari mangkonsumsi nasi dengan alasan ingin menurunkan berat badan. Kelompok kasus yakni responden obesitas sebagian besar sumber karbohidrat yang dikonsumsi hampir sama dengan responden non obesitas yaitu berasal dari nasi, roti, kentang, tepung terigu, gula pasir, bakso pentol, siomay, mie instan dan pasta. Penelitian ini sejalan dengan Pramono yang menyatakan bahwa tidak ada hubungan antara kecukupan karbohidrat dengan obesitas (Sasmito, 2013). Hasil penelitian yang dilakukan terhadap remaja di New York yang menemukan bahwa remaja dengan asupan karbohidrat yang rendah selama 12 minggu mengalami penurunan berat badan sebesar $9.9 \pm 9.3 \mathrm{~kg}$. Jika asupan karbohidrat ini dilakukan untuk waktu yang lebih lama maka akan didapatkan status gizi normal yang diinginkan (Sondike, 2003).

Pada asupan serat tidak terdapat perbedaan antara mahasiswi obesitas dengan non obesitas $(p=0,884)$. Nilai rerata asupan serat pada mahasiswi obesitas sebesar $6,3 \pm 3$ gram dan $6,1 \pm 2,4$ gram pada mahasiswi non obesitas, sehingga asupan serat pada kedua kelompok $100 \%$ kurang dari kebutuhan. Kebutuhan serat yang dianjurkan untuk kelompok wanita dewasa yaitu $25 \mathrm{gram} / \mathrm{hari}$. Hal ini sejalan dengan hasil penelitian Annisa dkk asupan serat pada penduduk dewasa $(>18$ tahun) di Provinsi Sumatra Barat, Jawa Barat, Jawa Tengah, dan Sulawesi Selatan memiliki tingkat asupan serat yang kurang (99\%). Hal ini diduga bahwa ada masalah didalam recall asupan serat yang berasal dari makanan yang dikonsumsi responden (Sasmito, 2013). Makaryani menyatakan asupan serat yang rendah dipengaruhi oleh pengetahuan serat yang masih rendah. Selain itu asupan serat juga dipengaruhi oleh gaya hidup, adat istiadat, dan kondisi fisiologis (Makaryani, 2013).

Tidakterdapatnyaperbedaanaktivitas fisik antara kelompok obesitas dengan non obesitas $(p=0,612)$. Aktivitas fisik ringan sebagian besar dimiliki oleh kedua kelompok baik mahasiswi obesitas (1221 $\pm 1,4 \mathrm{MET}$-menit/minggu) maupun non obesitas (1289 $\pm 1,7$ MET-menit/minggu). Namun, ditemukan pada kelompok kasus 
lebih banyak melakukan aktivitas fisik sedang $(33,3 \%)$ dibandingkan dengan kelompok kasus (25\%). Hal ini disebabkan karena adanya upaya mahasiswi dalam menurunkan berat badan dengan melakukan penambahan aktivitas fisik. Jenis aktivitas fisik yang dilakukan mahasiswi antara lain senam, berenang, jogging, workout, dan taekwondo. Hal ini sejalan dengan hasil penelitian Ruslie dkk yaitu mayoritas responden memiliki aktivitas fisik yang kurang, sedangkan sisanya memiliki aktivitas fisik cukup. Hal ini mungkin disebabkan karena mahasiswa FK UAJ terlalu sibuk dengan jadwal kuliah sehingga waktu yang bisa digunakan untuk berolahraga sangat terbatas. Tingginya jumlah mahasiswa yang memiliki aktivitas fisik kurang bisa disebabkan oleh kemajuan teknologi dan pengaruh globalisasi yang memicu semakin tidak pernah beraktivitas, seperti lebih menghabiskan waktunya untuk bermain komputer, menonton televisi, dan memilih bepergian dengan kendaraan bermotor (Ruslie, 2012).

\section{Kualitas Tidur, Durasi Tidur, Sindrom Makan Malam Terhadap Kejadian Obesitas}

Berdasarkan hasil penelitian kualitas dan durasi tidur berkaitan dengan status gizi subjek. Kualitas tidur yang buruk serta durasi tidur yang pendek lebih banyak dialami pada mahasiswi obesitas dibandingkan dengan mahasiswi non obesitas. Namun ditemukan hanya sedikit subjek yang mengalami sindrom makan malam. Hal ini dapat terjadi dikarenakan tidak semua subjek yang memiliki gangguan tidur bisa digolongkan kedalam sindrom makan malam, dikarenakan subjek dikatakan mengalami SMM apabila telah memenuhi tiga kriteria utama menurut Stunkard, et al yaitu tidak sarapan pagi, makan banyak di malam hari atau terbangun dari tidur disertai dengan makan dan tidur larut malam serta pengulangan seluruh kriteria selama tiga bulan (Lundgren, 2008). Sehingga kualitas dan durasi tidur dapat berkaitan dengan kejadian obesitas dapat disebabkan oleh faktor lain selain dari sindrom makan malam. Faktor-faktor utama tidur dihubungkan dengan kejadian obesitas seperti konsumsi makanan dan aktivitas fisik. Hubungan durasi tidur yang pendek dengan terjadinya obesitas pada orang dewasa dapat dijelaskan dengan beberapa mekanisme. Durasi tidur yang pendek dapat meningkatkan asupan energi dan menurunkan pegeluaran energi. Peningkatan asupan dan penurunan pengeluaran energi karena durasi tidur malam yang singkat, berkaitan dengan perubahan kadar berbagai hormon.
Salah satunya hormon leptin yang berperan dalam pengaturan keseimbangan energi sehingga perubahan kadar leptin dalam tubuh memengaruhi asupan maupun pengeluaran energi secara akut. Peningkatan asupan kalori dan selera makan yang berlebihan dapat dijelaskan dengan adanya peningkatan kadar ghrelin pada plasma darah setelah seseorang melewati malam tanpa tidur yang cukup. Hormon metabolisme lain yang juga dapat dipengaruhi oleh durasi tidur malam yang singkat adalah kadar kortisol yang lebih tinggi pada sore dan malam hari. Kortisol dapat memengaruhi kadar insulin dalam darah sehingga penimbunan lemak meningkat. Kemudian menurunnya kadar Growth hormone apabila seseorang tidak cukup tidur. Sehingga dapat merangsang penyerapan glukosa oleh sel, glikogenesis dan lipogenesis. Hal ini, apabila terjadi secara terus menerus dapat menyebabkan kegemukan (Safitri, 2015).

Tidur yang kurang (2-4 jam sehari) dapat mengakibatkan kehilangan 18\% leptin dan meningkatkan $28 \%$ ghrelin yang dapat menyebabkan bertambahnya nafsu makan kira-kira sebesar 23-24\%. Kemudian dapat disimpulkan dari beberapa penelitian bahwa secara keseluruhan, pengurangan tidur dapat meningkatkan asupan yang berlebih sebesar $>250 \mathrm{kkal} / \mathrm{hari}$. Beberapa pendapat dikemukakan bahwa dalam lingkungan yang sudah tersedia makanan, durasi tidur yang pendek dapat memberikan peluang peningkatan untuk makan, terutama jika sebagian besar waktu luang hanya dihabiskan dalam kegiatan tidak aktif (sedentary lifestyle) seperti menonton televisi yang biasanya diikuti dengan ngemil atau makan snack (Marfuah D, 2015). Meskipun berdasarkan pada hasil penelitian zat gizi makro responden masih kurang dari kebutuhan perindividu. Hal ini dapat disebabkan karena terjadinya bias pada saat recall karena metode ini sangat membutuhkan kejujuran responden dan terkadang hasil yang diperoleh kurang memuaskan. Hal ini disebabkan oleh beberapa faktor, antara lain: ketidaksesuaian dalam menggunakan alat ukur, waktu pengumpulan data yang tidak tepat, instrumen tidak sesuai dengan tujuan, ketelitian alat timbang makanan, kemampuan petugas pengumpulan data, daya ingat responden, daftar komposisi makanan yang tidak sesuai dengan makanan yang dikonsumsi responden dan interpretasi hasil yang kurang tepat (Silvia, 2011). 


\section{KESIMPULAN DAN SARAN}

Terdapat perbedaan kualitas tidur, durasi tidur dan asupan protein antara mahasiswi obesitas dan non obesitas di Fakultas Kedokteran Universitas Diponegoro

\section{DAFTAR PUSTAKA}

Aprilianti F, Kawengian S E, Bolang A S. (2013). Hubungan Asupan Lemak dengan Kadar Hs-CRP Serum pada Mahasiswa Obes dan Tidak Obes di Fakultas Kedokteran Universitas Sam Ratulangi Manado. eBM; 1(1): 252 - 259.

Arendt J. (2000). Melatonin, Circadian Rhythms, And Sleep. N Engl J; 343(15): 1114-1116.

Bayon V, Leger D, Gomez-Merino D, Vecchierini MF, Chennaoui M. (2014). Sleep debt and obesity. Ann Med; 46(5):264-272.

Bingku TA, Bidjuni H, Wowiling F. (2015). Perbedaan Tingkat Stres Mahasiswa Reguler dengan Mahasiswa Ekstensi dalam Proses Belajar di Program Studi IImu Keperawatan Fakultas Kedokteran Unsrat Manado. Jurnal Gizi Klinik Indonesia; 11(4): $1-7$.

Dinn do Q. (2008). Depresion and stress among the first year medical student in University of medicine and pharmacy Hochiminh City Vietnam. J Health Res; 22: 1 - 4. Fandiani YM, Wantiyah, Juliningrum PP. (2017). The effect of dzikir therapy on sleep quality of college students at school of nursing University of Jember. NurseLine Journal; 2(1): 52-60.

Farooqi IS, Jebb SA, Langmack G, Lawrence E, Cheetham CH, Prentice AM, et al. (1999). Effects of Recombinant Leptin Therapy in a Child with Congenital Leptin Deficiency. $N$ Engl J Med; 341(12): 879-84. Gluck ME, et al. (2001). Night Eating Syndrome Is Associated with Depression, Low Self-Esteem, Reduced Daytime Hunger, and Less Weight Loss in Obese Outpatients; 9(4): 264-267.

Hamrik Z, Sigmundová D, Kalman M, Pavelka J, Sigmund E. (2014). Physical activity and sedentary behaviour in Czech adults: Results from the GPAQ study. Eur J Sport Sci: 14; 193 - 198.

Khomsan A. (2003). Pangan dan gizi untuk kesehatan. Edisi 1. Jakarta: PT Raja $G$ reafindo Persada.p.90-3,120-2.

Lestari R. (2018). Hubungan Tingkat Asupan Energi dan Durasi Tidur dengan
Indeks Massa Tubuh Mahasiswa Fakultas IImu Kesehatan. Universitas Muhammadiyah Surakarta; $1-6$. Lundgren JD, Allison KC, O'ReardonJP and Albert J. Stunkard, M.D. (2008). A Descriptive Study of Non-obese Persons with Night Eating Syndrome and a Weight-Matched Comparison Group.NIH-PA; 9(3): 343 - 351. Makaryani. (2013). Hubungan Konsumsi Serat dengan Kejadian Overweight pada Remaja Putri SMA Batik 1 Surakarta. [Skripsi]. Surakarta: Universitas Muhammadiyah Surakarta. Marfuah D. (2015). Kualitas Tidur Hubungannya dengan Obesitas pada Anak Sekolah DasardiYogyakarta.Profesi;1(12):47-48.

Melvy P, Eka AP, Muhammad II, Wilson, Rozalina. (2017). Hubungan Tingkat Stres dengan Indeks Massa Tubuh Mahasiswa PSPD FK UNTAN. Jurnal Vokasi Kesehatan; 3 (2): 47 - 56. Milano W, De Rosa M, Milano L, Capasso A. (2012). Night eating syndrome: An overview. Journal of Pharmacy and Pharmacology; 64: 2-10. Musradinur. (2016). Stres dan Cara Mengatasinya dalam Perspektif Psikologi. Jurnal Edukasi; 2(2): 183-200. Muzamil. (2014). Hubungan Antara Tingkat Aktivitas Fisik dengan Fungsi Kognitif pada Usila di Kelurahan Jati Kecamatan Padang Timur. J Kesehat Andalas; 3(2) 202 - 203. National Sleep Foundation. (2010). How much sleep do we really need? Washington, DC: National Sleep Foundation. [cited 15 november 2017] available from http://www.sleepfoundation. org/article/how-sleep-works/howmuch-sleep-do-we-really-need Omar A. (2007). Night Eating Syndrome with Morbid Obesity and Dysthymia: A Case Report -A Psychobiological Approach. Med \& Health; 2(2) : 154-157.

Parastika TD. (2012). Gambaran dan FaktorFaktor yang berhubungan dengan Sindrom Makan Malam pada Mahasiswa Fakultas Teknik Universitas Indonesia [Skripsi]. Depok: Universitas Indonesia. Prameswari SP, Aisyah S, Mifbakhuddin. (2013). Hubungan Obesitas Dengan Citra Diri dan Harga Diri pada Remaja Putri di Kelurahan Jomblang Kecamatan Candisari Semarang. Jurnal 
Keperawatan Komunitas; 1(1): 52-61

Profil Kesehatan Kabupaten Semarang 2016. (2016). Dinas Kesehatan Kabupaten Semarang. p. 29

Riset Kesehatan Dasar (RISKESDAS) Tahun 2013. (2013). Jakarta: Badan Penelitian dan Pengembangan Kesehatan Kementrian Kesehatan RI. p. 224 - 226.

Ruslie R H, Darmadi. (2012). Analisis Regresi Logistik untuk FaktorFaktor yang Mempengaruhi Status Gizi Remaja. Majalah Kedokteran Andalas; 1(36): $62-72$.

Safitri DE, Trini S. (2015). Difference of sleep duration of obese and non-obese adults: meta-analysis cross-sectional studies 2005-2012; Penelitian Gizi dan Makanan; 38 (2): 121 - 132.

Sasmito PD. (2013). Hubungan Asupan Zat Gizi Makro ( Karbohidrat ,Protein , Lemak) dengan Kejadian Obesitas pada Remaja Umur 13- 15 Tahun di Propinsi Dki Jakarta ( Analisis Data Sekunder Riskesdas 2010). Nutr Diaita;7(1); 16-23.

Şendir M, Acaroğlu R, Kaya $H$, Erol S, Akkaya Y. (2007). Evaluation of quality of sleep and effecting factors in hospitalized neurosurgical patients. Neurosciences; 12: 226-31.

Serly V, Sofian A, Ernalia Y. (2015). Hubungan body image, asupan energy dan aktivitas fisik dengan status gizi pada mahasiswa fakultas kedokteran universitas riau angkatan 2014. JOM FK; 2(2): 1 - 14.

Sharma S, Kavuru M. (2010). Sleep and metabolism: An overview. Int J Endocrinol: 1 - 12.

Silvia MN, Marudut, Jus'at I. (2011). Konsumsi Zat-Zat Gizi Menurut Metode RecallRecord Berdasarkan Waktu Makan Remaja Putri. Nutrire Diaita; 3(2): 85- 97.

Sondike SB, Copperman N, Jacobson MS. (2003). Effects of a lowcarbohydrate diet on weight loss and cardiovascular risk factor in overweight adolescents. J Pediatr; 142: 253-58. Spiegel K, Leproult R, L'hermite-Baleriaux M, Copinschi G, Penev PD, and Van Cauter E. (2004). Leptin levels are dependent on sleep duration: relationships with sympathovagal balance, carbohydrate regulation, cortisol, and thyrotropin. J Clin Endocrinol Metab; 89(11):5762 - 5771.

Sugianti E, Hardinsyah, Afriansyah N. (2009). Faktor resiko obesitas sentral orang dewasa di DKI Jakarta analisis lanjut data RISKESDAS 2007. Gizi Indon; 32(2):105,112.

Sulistiyani C. (2012). Beberapa Faktor yang Berhubungan dengan Kualitas Tidur pada Mahasiswa Fakultas Kesehatan Masyarakat Universitas Diponegoro Semarang. Jurnal Kesehatan Masyarakat; 1(2): 280 - 292.

Taheri S, Lin L, Austin D, Young T, Mignot E. (2004). Short sleep duration is associated with reduced leptin, elevated ghrelin, and increased body mass index. PLoS Med; 1(3): 210 - 217. Wahyuningsih R. (2013). Penatalaksanaan Diet pada Pasien. Yogyakarta: Graha IImu.p.21 - 22.

Wardani DAK, Huriyati E, Mustikaningtyas M, Hastuti J. (2015). Obesitas, body image, dan perasaan stres pada mahasiswa di Daerah Istimewa Yogyakarta. J Gizi Klin Indones; 11(4): 161-169.

Wei M, Russell DW, Zakalik RA. (2005). Adult attachment, social self-efficacy, self-disclosure, loneliness, and subsequent depression for freshman college students: A longitudinal study. J Couns Psychol; 52: 602-14.

World Health Organization. (2011). Nutrition Landscape Information System: Country profile indicators. Geneva, Switzerland: World Health Organization. [cited 28 november 2018]. Available from: www.who.int Yannakoulia M, Ntalla I, Papoutsakis C, Farmaki AE, Dedoussis G V. (2010). Consumption of vegetables, cooked meals, and eating dinner is negatively associated with overweight status in children. J Pediatr.; 157 (5): 815 - 820. 